\title{
Optimization Tile Waste Treatment as Pozzoland Active Material on Paving Block with Variation Parameter of Fuel Temperature
}

\author{
Nanin Meyfa Utami $^{1,}{ }^{*}$, Dwi Nurtanto ${ }^{1}$, and Rossi Nain Nopan Juwari ${ }^{2}$ \\ ${ }^{1}$ Lecturer Department of Civil Engineering, Faculty of Engineering, University of Jember, Indonesia \\ ${ }^{2}$ Undergraduate student of Department of Civil Engineering, Faculty of Engineering, University of \\ Jember, Indonesia
}

\begin{abstract}
The abundance of tile waste is used as a material innovation in the manufacture of concrete and paving. However, the results of research done by new researchers mostly only as filler material. The paving block which was added as a cement powder substitution material decreased compressive strength along with the tile waste percentage addition (Ridwan, 2017). Thus, researchers try to optimize tile waste treatment before being used in the paving blocks with raise the fuel temperature up to $900^{\circ} \mathrm{C}$ to obtain more amorphous pozzoland. Waste tile contains $\mathrm{SiO}_{2}$, $\mathrm{CaAl}_{2} \mathrm{Si}_{2} \mathrm{O} 8, \mathrm{Fe}_{2} \mathrm{O}_{3}$ and $\mathrm{Mg}_{2}$ ( $\mathrm{SiO}$ 4) on the testing of XRD so compliant as pozzoland material. This research used powder waste as a material of cement substitution with $0 \%, 5 \%, 7 \%$, and $10 \%$ of cement weight with variation of fuel temperature $750{ }^{\circ} \mathrm{C}, 800{ }^{\circ} \mathrm{C}, 850{ }^{\circ} \mathrm{C}$ and $900^{\circ} \mathrm{C}$. The results showed that by increasing the fuel temperature up to $900^{\circ} \mathrm{C}$ compressive strength increased by $5.9 \%$ and water absorption decreased by $14.5 \%$. However, by increasing the percentage of tile waste, compressive strength decreased up to $7.2 \%$. Testing is supported by the SEM results wich indicate that the greater percentage used then the paving surface is also more hollow.
\end{abstract}

Keywords: temperature, tile waste, paving block, pozzoland active

\section{Introduction}

Along with the increasing population in the world then the infrastructure requirements are also increasing. Such as the provision of housing or buildings, bridges up to the road either from the pavement or rural roads made up of paving blocks. While, raw materials making paving blocks that available in nature are not all can be recycled. For example, cement, in the process of manufacture using limestone and other raw materials that can not be recycled. The use of cement as an ingredient of paving block is considered the most expensive among other materials. So it is necessary to do an innovation research on cement, one of them by using the waste of tile as a mixture material in manufacturing paving block.

* Corresponding author: nanin.meyf@gmail.com 
The abundance of tile waste has been widely used as an innovation material in the technology of making concrete and paving. However, the results of research that has been done by many new researchers, just as a filler on the manufacture of concrete and paving. As done by Ridwan (2017) who tried to use a tile waste used as a cement replacement material in the manufacture of paving blocks. However, the conclusion of his research mentioned that the greater percentage of tile waste used in paving block makes the compressive strength decreasing. Waste tile compound used has $\mathrm{SiO}_{2}, \mathrm{Al}_{2} \mathrm{O}{ }_{3}, \mathrm{Fe}_{2} \mathrm{O}_{3}$ which has the amorphous content of less than $85.99 \%$ came from the tile that is burned at a temperature of $700^{\circ} \mathrm{C}$ for 14 hours. At the fuel temperature indicates that tile waste powder material has not been reactive and has not been able to act as cement replacement material so that it only serves as filler. Thus the content of pozzoland in the tile waste has not been reactive, so it is necessary to optimize the processing of tile waste by raising the temperature to get pozzoland active content. At the furnicing of $900^{\circ} \mathrm{C}$ the content of the essential compounds are Silica, Quartz, Flint, and Crystals, which are the main constituents of cement.

Research conducted by Ridwan (2017), using tile powder for 14 hours furnicing with a temperature of $700{ }^{\circ} \mathrm{C}$ as a substitution material on cement in the manufacture of paving blocks. The conclusion of his research mentioned that with the addition of tile powder does not make the compressive strength of paving block increases, in other words powder tile can not be used as pozzoland but as a filler. Although the tile powder originating from the village of Kunir Lumajang has a percentage content of $\mathrm{SiO}_{2}, \mathrm{AlOO}_{3}, \mathrm{FeOO}$ compounds which have been in accordance with the pozzoland reactivity standard of $85.99 \%$ in accordance with ASTM C 618-94 and SNI 15-0302-89 (Frank Edwin, 2007). However, in its use is still limited as a filler material has not become material substitution. So that important to processing or treatment first before being used used as a mixture of making paving block.

Optimization of tile waste treatment in this research is done by increasing the temperature of furnicing to get the reactivity of clay as active pozzoland material from tile waste. The proportion of paving using a ratio of 1: 4 of cement: sand with the number of fas 0,275 and the percentage of tile waste by $0 \%, 5 \%, 7,5 \%$, and $10 \%$. Waste tile is burned with variation of furnace temperature that is: $750{ }^{\circ} \mathrm{C}, 800^{\circ} \mathrm{C}, 850{ }^{\circ} \mathrm{C}$ and $900^{\circ} \mathrm{C}$ to know the optimal furnicing temperature in obtaining the reactivity of the material. In addition, it is intended to know the physical and mechanical properties of paving blocks that have been added powder of tile waste and tested the chemical content contained there in by XRD (XRay Diffaction) test and SEM (Scanning Electron Microscopy) test. Mechanical properties to be known is the effect of adding furnace temperature, the effect of adding the percentage of tile powder to the compressive strength of paving, porosity, absorption and performance of the paving block.

\section{The Literature}

\subsection{Lumajang Original Press Tile}

\subsubsection{The Production Method of Tile Press in Lumajang Area}
a. Red soil (mountain soil) $60 \%$
b. Ordinary soil (garden land) $40 \%$
c. Water

\subsubsection{Processing Method}

d. Mix all ingredients by adding a little water

e. Grinding all ingredients as much as 2 times the grinding process 
f. Tile printing

g. The process of drying

h. Furnicing process with temperature of $700^{\circ} \mathrm{C}$ for 14 hours

\subsection{Tile Waste}

Limbah genteng merupakan sisa dari proses produksi genteng. This waste is in the form of solid flakes after the furnicing process due to cracks in the roof or impact during furnicing. This waste is in the form of solid flakes after the furnace process because cracks. In one tile production a total of 6000 seeds, waste produced as many as 100 seeds.

Based on the data then the need for processing of waste generated so that waste is not wasted. In addition, based on the materials used in the production of clay roofs, during the combustion process carried out in temperatures exceeding $900^{\circ} \mathrm{C}$, there will be a compound such as Silica (Krisnanda et al, 2014). Silica is the subject for changing the shape and volume of clay at a certain temperature. Some changes are fixed and nonreturnable (conversions) and others are reversible. In order for the clay to be transformed into a ceramic must be through the combustion process with a temperature exceeding $900^{\circ}$ C. After going through the temperature the clay will change into a solid, hard, and permanent mineral. This caracter is similar to the cement when reacting with water, and at room temperature will experience hardening.

\subsection{The Content of Silica in Tile Waste}

Silica is a chemical compound with the molecul formula $\mathrm{SiO} 2$ (silicon dioxsida) obtained from mineral silica, and crystal synthesis. Mineral silica is a compound found in mineral deposits such as quartz sand, granite, and fledsfar containing crystalline silica ( $\mathrm{SiO}$ ) (Bragman and Gonealves, 2006; Della et al 2002). Apart from the natural form, silica with trimite crystal structure can be obtained by heating quartz sand at $870{ }^{\circ} \mathrm{C}$ and when heating is carried out at $1470^{\circ} \mathrm{C}$, silica can be obtained with a cristobalite structure (Cotton and Wilkinson, in U, Melinda, 2015). The silica content found in the tile-making material is $47 \%$ ( $\mathrm{SiO}$ ) (Kusuma, Dwi 2013). Based on the content of clay contained in the tile, after the burning process is expected to contain silica content that can be used as pozzoland material. Details of the percentage of silica on the tile can be seen by XRD testing.

\subsection{Paving Block}

Concrete brick (paving block) is a building material composition made from a mixture of portland cement or similar hydrolysis materials, water and aggregate with or without other additives which does not reduce the quality of this concrete brick. Paving blocks are composed of a fine aggregate mixture of sand with cement and water, the mixture also known as mortar (non plaster). Paving blocks / mortar are often called mortars or specimens,it is a blends consisting of sand, binder and water. If mortar is made by adding special ingredients (such as fiber, powder or wood grain, etc.) on lime mortar or cement mortar, then it is called a special mortar (Tjokrodimuljo, 1996). 


\section{The Research Methodology}

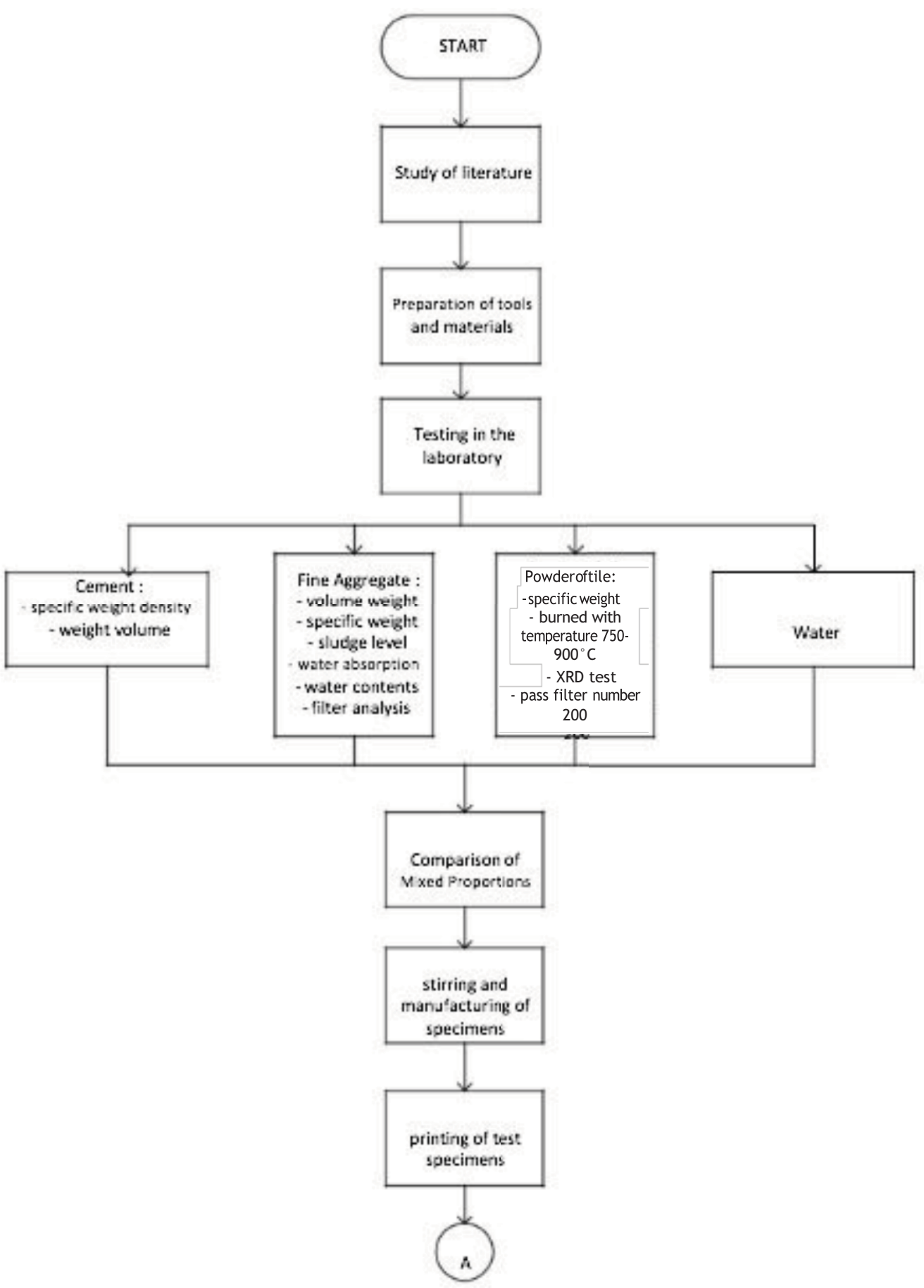




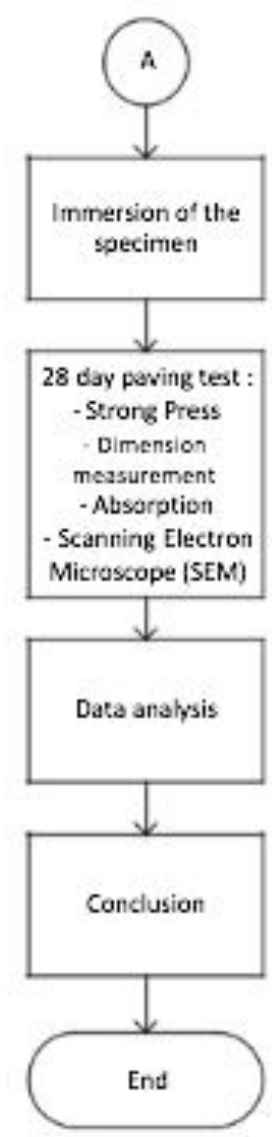

\section{The Result}

\subsection{XRD (X-Ray Diffraction) Result Test}

X-Ray Diffraction (XRD) testing was performed on tile waste that burned at 750, 800, 850 and $900^{\circ} \mathrm{C}$ with 14 hours burning duration in order to know the minerals contained therein. Primarily to find the content of silica and alumina because it will be used as a cement substitute material in the manufacture of paving blocks. The XRD analysis was recorded with long angles showing diffraction patterns with $2 \theta$ angles from range $5^{\circ}$ to $90^{\circ}$ at a rate of $0.02^{\circ} / \mathrm{sec}$. The results of X-ray diffraction pattern testing on the press tile powder are presented in figures 4.1 to 4.4 : 
4.1.1 XRD Test of Tile Waste at Temperature $750^{\circ} \mathrm{C}$

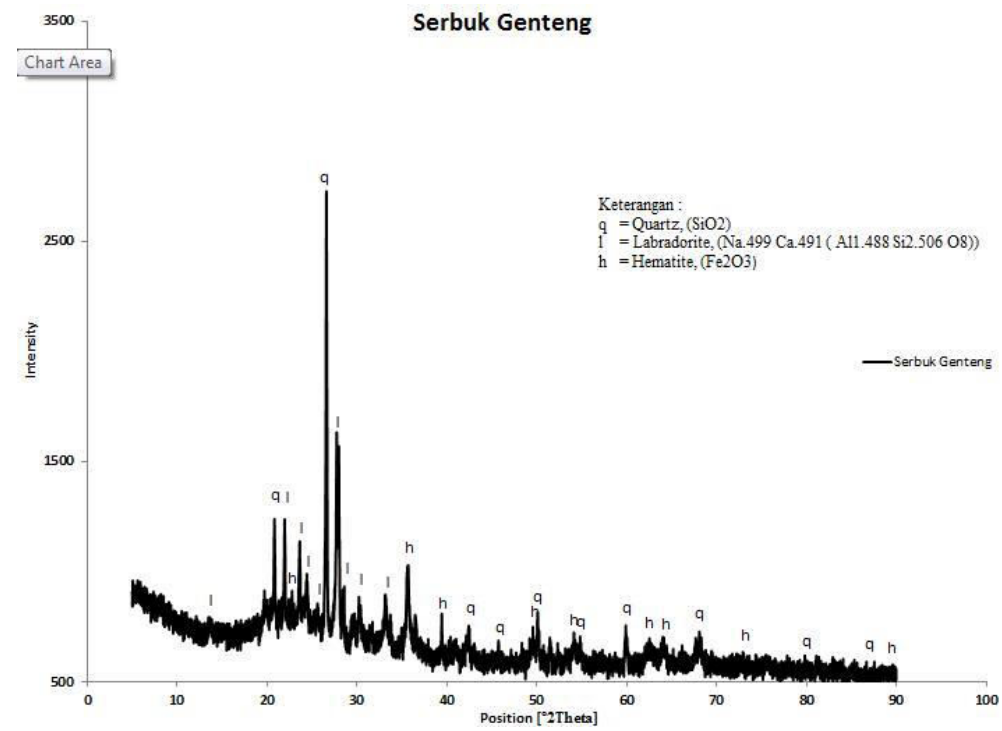

Fig. 1. Graph of XRD analysis of tile waste $750^{\circ} \mathrm{C}$

Figure 1 shows that the highest peak is the mineral Quartz (SiO2). Besides Quartz analysis results at a temperature of $750^{\circ} \mathrm{C}$ is also contained mineral types Labradorite (Na.499 Ca.491 (A11.488 Si2.506 O8)) and hematite (Fe2O3).

\subsubsection{XRD Test of Tile Waste at Temperature $800^{\circ} \mathrm{C}$}

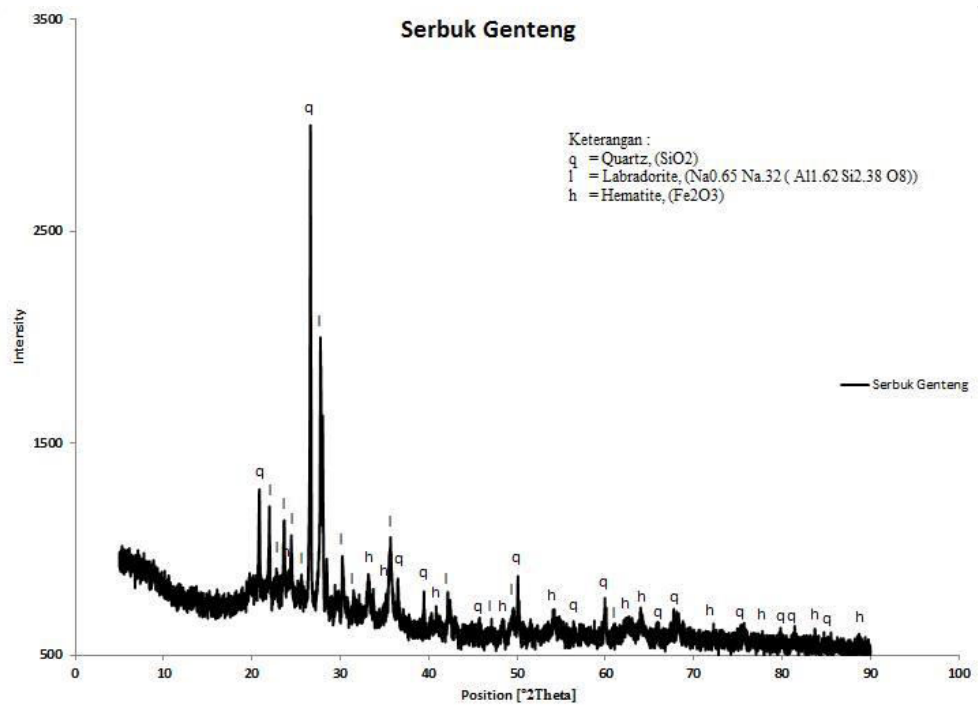

Fig. 2. Graph of XRD analysis of tile waste $800^{\circ} \mathrm{C}$ 
Figure 2 shows that the highest peak is the mineral Quartz (SiO2). Besides Quartz analysis results at a temperature of $800^{\circ} \mathrm{C}$ is also contained mineral types Labradorite $(\mathrm{Na} 0.65 \mathrm{Na} .32$ (Al1.62 Si2.38 O8)) and hematite (Fe2O3).

\subsubsection{XRD Test of Tile Waste at Temperature $850^{\circ} \mathrm{C}$}

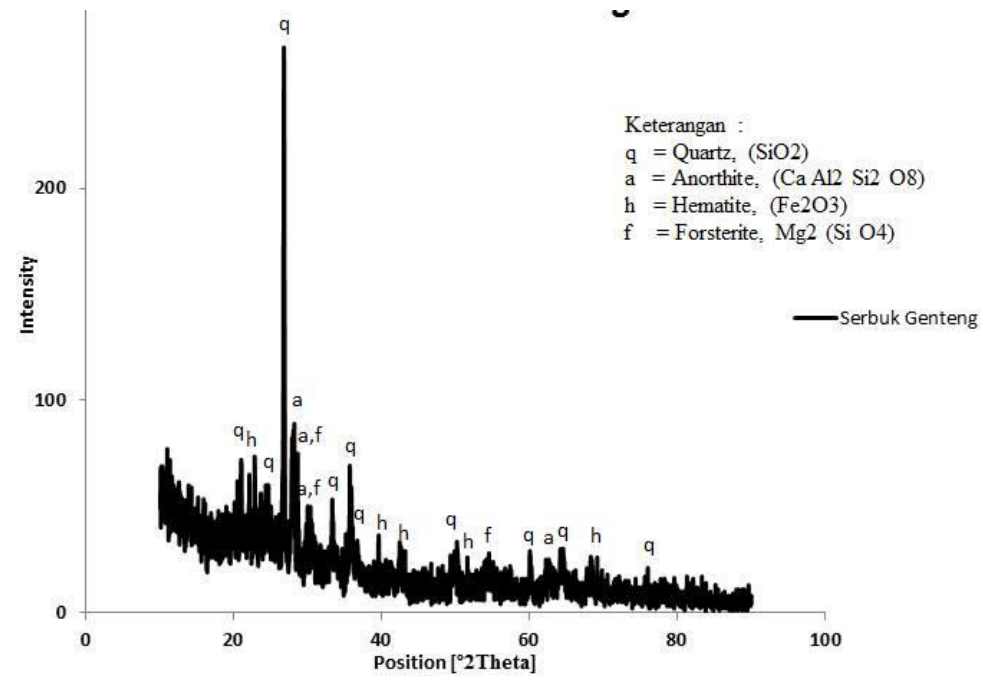

Fig. 3. Graph of XRD analysis of tile waste $850^{\circ} \mathrm{C}$

Figure 3 shows that the highest peak is the mineral Quartz (SiO2). Besides Quartz analysis results at $850^{\circ} \mathrm{C}$ there is also a kind of mineral hematite (Fe2O3), Anorthite (CaAl2Si2O8) and Forsterite $(\mathrm{Mg}(\mathrm{SiO} 4))$.

\subsubsection{XRD Test of Tile Waste at Temperature $900^{\circ} \mathrm{C}$}

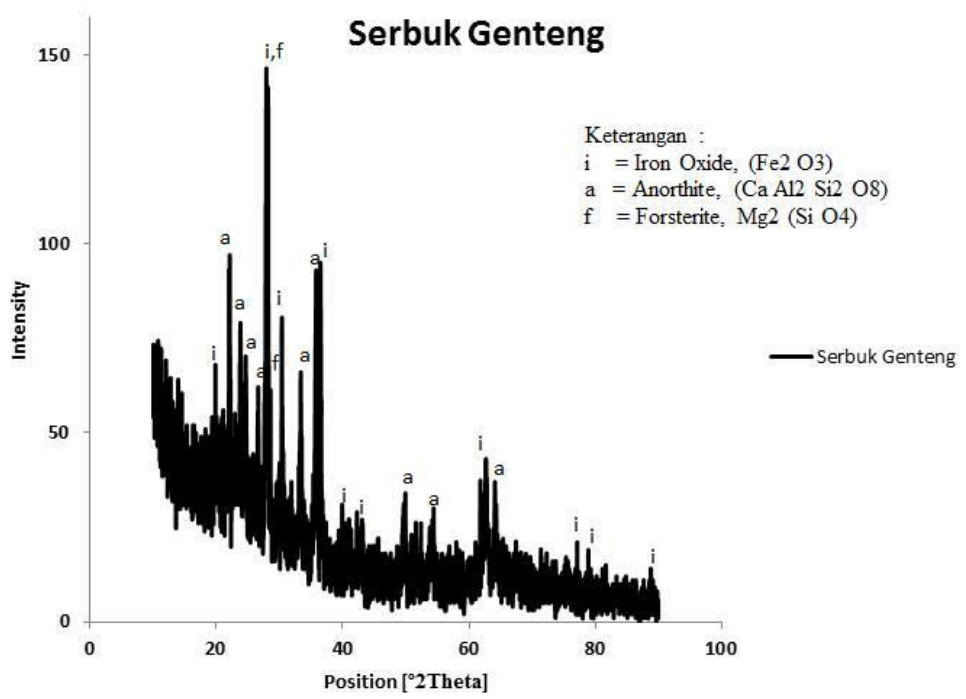

Fig. 4. Graph of XRD analysis of tile waste $900^{\circ} \mathrm{C}$ 
Figure 4 shows that the higest peak is the mineral Anorthite (CaAl2Si2O8). Besides Anorthite result at temperature $900^{\circ} \mathrm{C}$ there is also kind of mineral Iron Oxide(Fe2O3) and Forsterite $(\mathrm{Mg}(\mathrm{SiO} 4))$.

Table 1. Minerals in tile waste contained in portland cement

\begin{tabular}{|c|l|}
\hline Temperature $\left({ }^{\circ} \mathrm{C}\right)$ & Minerals (Compounds) \\
\hline \multirow{2}{*}{$750{ }^{\circ} \mathrm{C}$} & Quartz (Silica), $\left(\mathrm{SiO}_{2}\right)$ \\
\cline { 2 - 2 } & Hematite (Iron), $\left(\mathrm{Fe}_{2} \mathrm{O}_{3}\right)$ \\
\hline \multirow{2}{*}{$800^{\circ} \mathrm{C}$} & Quartz (Silica), $\left(\mathrm{SiO}_{2}\right)$ \\
\cline { 2 - 2 } & Hematite (Iron), $\left(\mathrm{Fe}_{2} \mathrm{O}_{3}\right)$ \\
\hline \multirow{2}{*}{$850^{\circ} \mathrm{C}$} & Quartz (Silica), $\left(\mathrm{SiO}_{2}\right)$ \\
\cline { 2 - 2 } & Hematite (Iron), $\left(\mathrm{Fe}_{2} \mathrm{O}_{3}\right)$ \\
\hline $900{ }^{\circ} \mathrm{C}$ & Iron Oxide(Iron), $\left(\mathrm{Fe}_{2} \mathrm{O}_{3}\right)$ \\
\hline
\end{tabular}

Source: XRD Test Results (X-Ray Diffraction)

Based on the graph of XRD analysis of tile waste in Figure 1 to 4 , the dominant compounds in each temperature are Quartz (Silica) $\left(\mathrm{SiO}_{2}\right)$ and Hematite (Iron) $\left(\mathrm{Fe}_{2} \mathrm{O}_{3}\right)$ where the minerals are minerals contained in Portland cement. Kartika Ratri et al (2008) in his research said that with variations of burning temperature of $600^{\circ} \mathrm{C}, 700^{\circ} \mathrm{C}, 800^{\circ} \mathrm{C}$ and $900^{\circ} \mathrm{C}$ showed that by increasing the combustion temperature will increase the value of compressive strength and decrease the water absorption value of tile.

\subsection{Compressive Strength Testing Results}

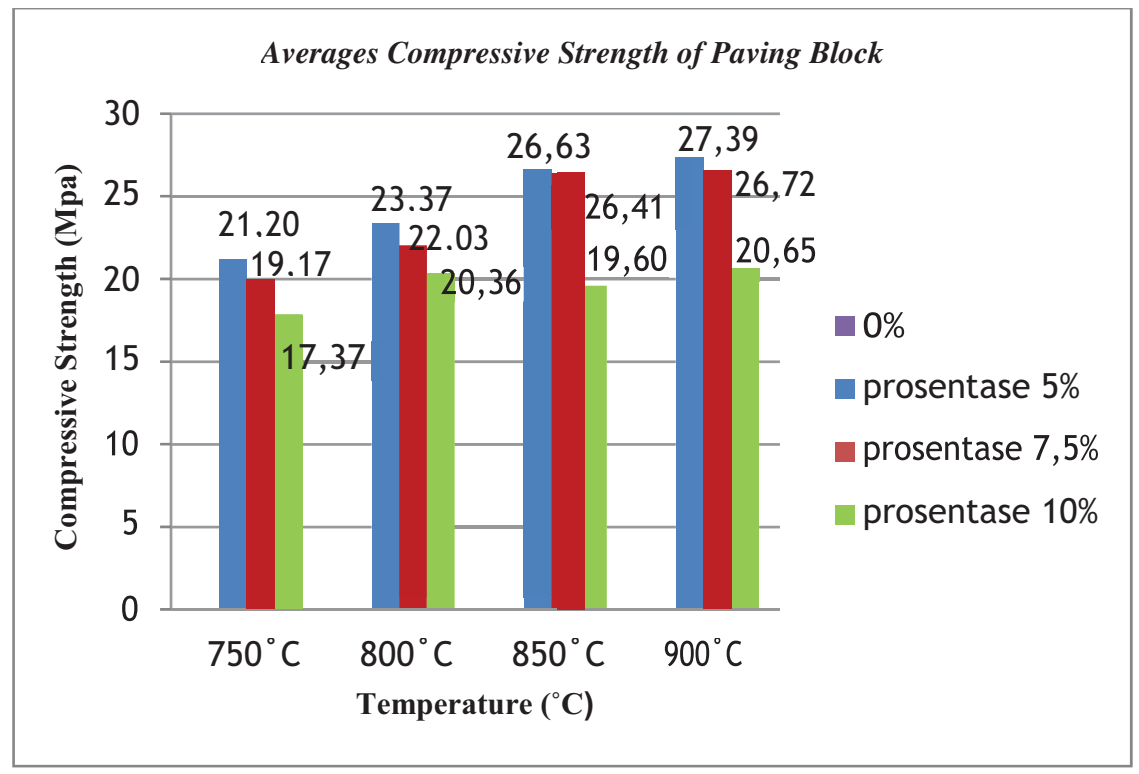

Fig. 5. Average Graph of Compressive Strength of Paving Block Test Results 
Tile waste has an increasingly reactive compound composition in every increase in temperature variation. It can be seen from the test results of XRD in Figure 1 to 4 Some researchers Lea and Kuroda, in Ade Ilham (2005) stated that the reactive nature of pozzolan and bond strength in the layer of cement-aggregate aggregates is highly dependent on the chemical composition of the pozzolan material. Kuroda, in Ilham (2005) also explained that the increase in bond strength in cement aggregate layers depends on the chemical composition, especially the $\mathrm{SiO} \square$ and $\mathrm{CaO}$ content. The decrease of compressive strength in paving block is caused because the pozzoland material used has not been reactive at 750 ${ }^{\circ} \mathrm{C}$ and will continue to increase its reactivity power along with the increase of variation of fuel temperature. This proves that the powder powder can not be used as pozzoland but as a filler, where with a smooth fraction will fill the cavity in the concrete so as to increase the density of the paving block.

Table 2. Testing data compressive strength based on temperature rise and addition of percentage of tile waste

\begin{tabular}{|c|c|c|c|c|}
\hline \multirow{2}{*}{$\begin{array}{c}\text { Percentage of Tile } \\
\text { Waste }\end{array}$} & \multicolumn{4}{|c|}{ Compressive Strength (Mpa) } \\
\cline { 2 - 5 } & $750{ }^{\circ} \mathrm{C}$ & $750{ }^{\circ} \mathrm{C}$ & $750{ }^{\circ} \mathrm{C}$ & $750{ }^{\circ} \mathrm{C}$ \\
\hline $5 \%$ & 21,2 & 23,37 & 26,63 & 27,39 \\
\hline $7,5 \%$ & 19,17 & 22,03 & 26,41 & 26,72 \\
\hline $10 \%$ & 17,87 & 20,36 & 19,6 & 20,65 \\
\hline
\end{tabular}

Source: laboratory testing 2018

From the data table 2 it can be concluded that by increasing the fuel temperature, the compressive strength of the paving block increased by $5.9 \%$. However, by increasing the percentage of addition of tile waste into paving block mixture, the resulting compressive strength decreased by $7.2 \%$.

\subsection{Water Absorption Test Result}

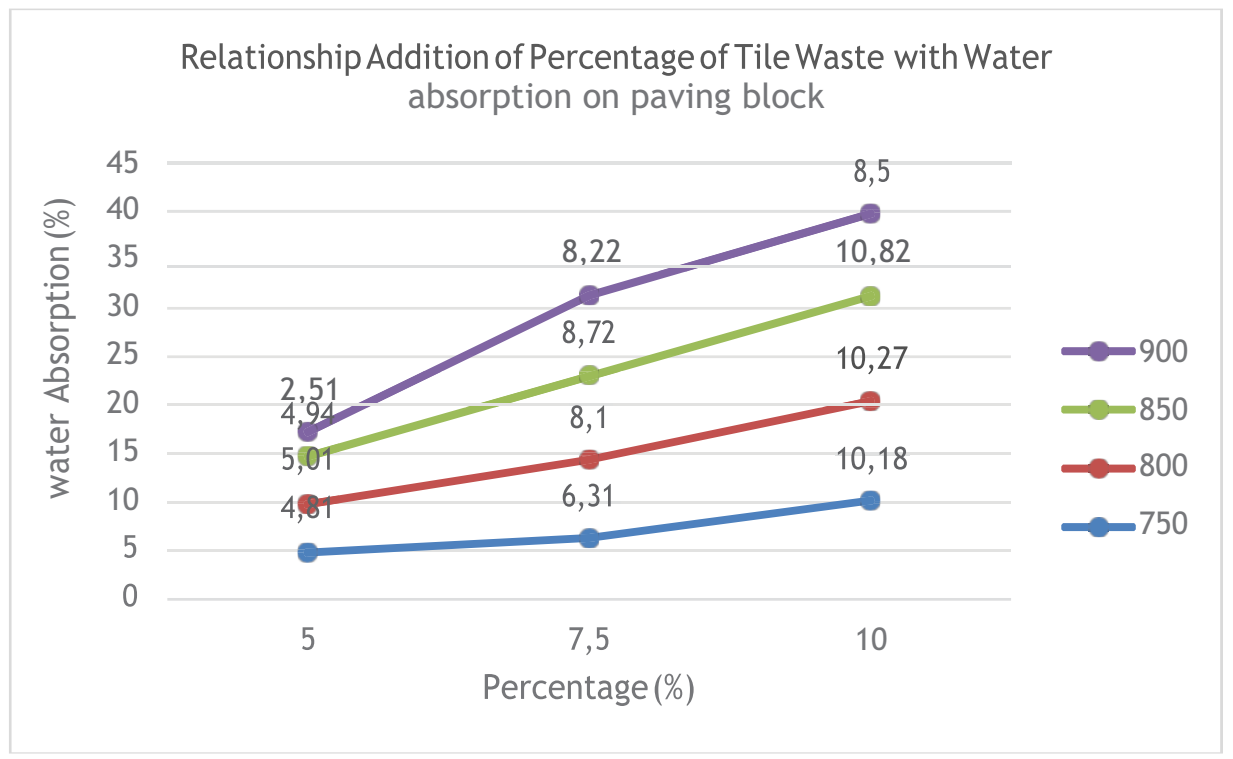

Fig. 6. The Graph Relationship of Percentage Tile Waste with water absorption on paving block 
Figure 6 explains that each additional percentage of tile waste makes the value of water absorption is increasing. Paving block without the addition of tile waste has the smallest absorption of $2.51 \%$. The value of water absorption is increasing successively on the percentage of $5 \%, 7 \%$ and $10 \%$ at each tread burning temperature of $750{ }^{\circ} \mathrm{C}, 800{ }^{\circ} \mathrm{C}, 850{ }^{\circ} \mathrm{C}$, and $900{ }^{\circ} \mathrm{C}$.

According to SNI-03-0691-1996 requirements for water absorption average of the maximum allowed in the compressive strength of $20 \mathrm{MPa}$ plan is $6 \%$. Variations that meet the requirements of water absorption are the variations in the temperature of burning tile waste $750{ }^{\circ} \mathrm{C}, 800{ }^{\circ} \mathrm{C}, 850{ }^{\circ} \mathrm{C}$, and $900{ }^{\circ} \mathrm{C}$ percentage of $5 \%$ with water absorption value $4,81 \%, 5,01 \%, 4.94 \%$ and $2.51 \%$ respectively.

\subsection{SEM (Scanning Electron Microscope) Test Results}

SEM Testing (Scanning Electron Microscope) is performed to determine the physical properties of concrete. The SEM (Scanning Electron Microscope) test is performed by Tabletop Microscope 3030 plus means to know the surface portrait of the test specimen as supporting data in the compressive strength test of paving block without or with the addition of tile waste. This test is also conducted to determine the homogeneity of cavities that occur in each composition of the specimen so that it can be used in drawing conclusions in this study.

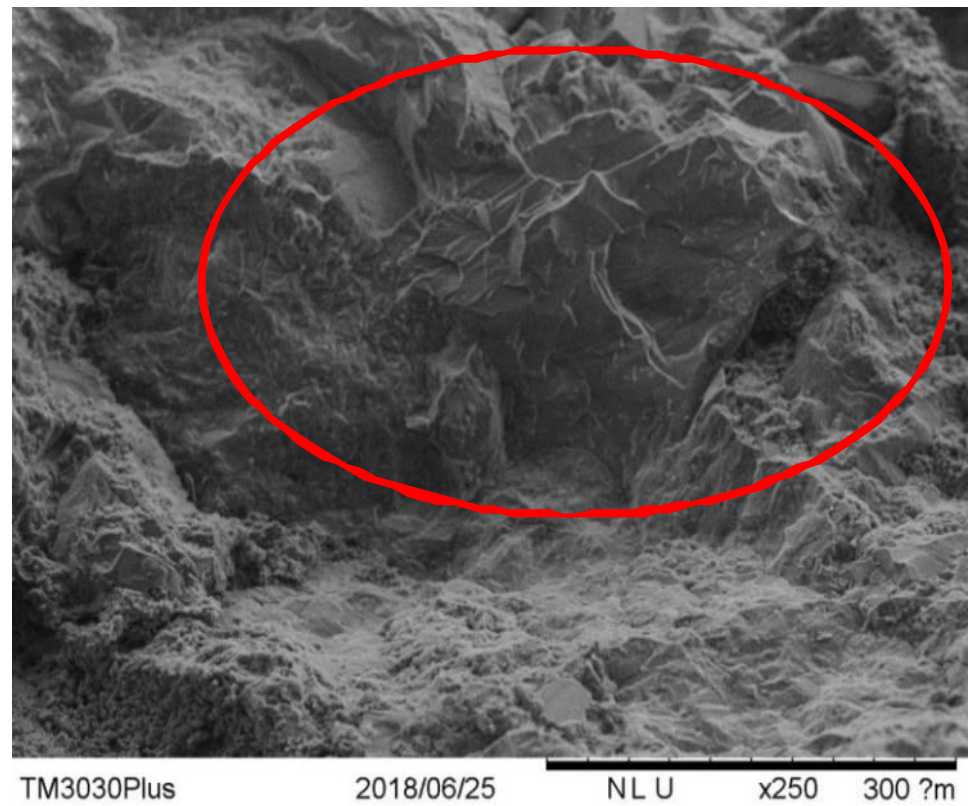

Fig. 7. Test Results SEM without the addition of block paving tiles Waste 250X Magnification

Figure 7 is an image of the SEM test result on a paving block sample without the addition of tile waste with 250x magnification. The red circle shows all the paving block materials such as cement, sand and water have mixed together into homogeneous bonds. Good bonding makes the shape of a paving block becomes solid. This makes the compressive strength of the paving block without the addition of tile waste to be higher than othervariations. 


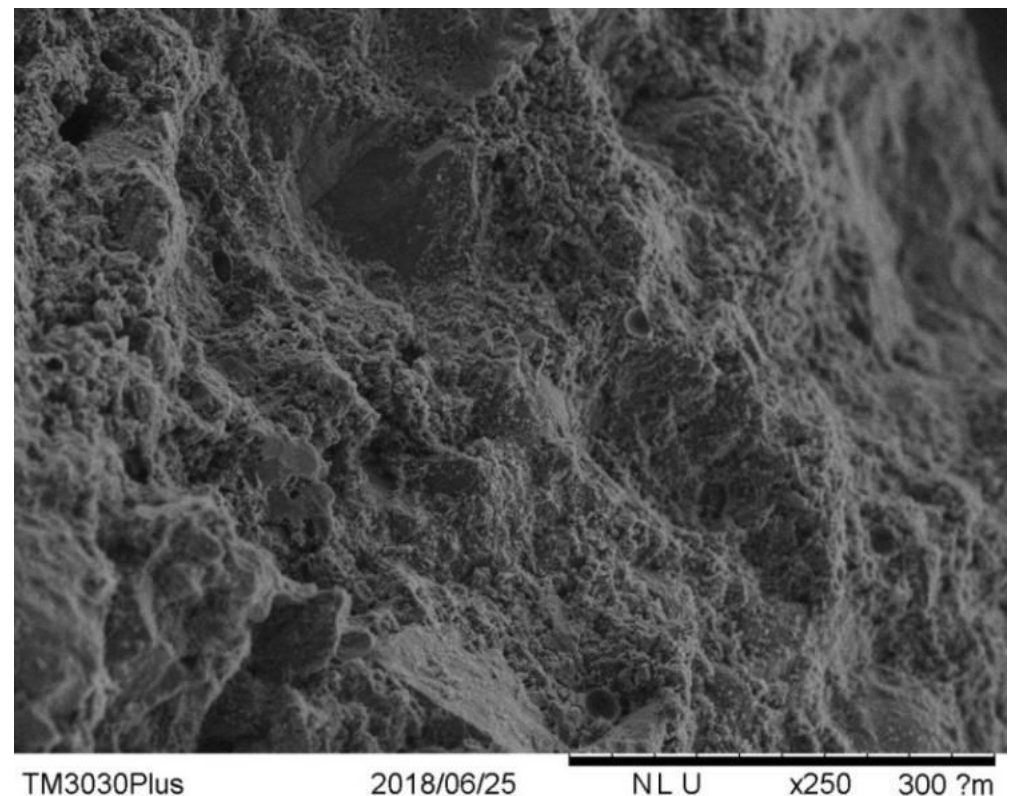

Fig. 8. SEM Test of paving block with $5 \%$ tile waste addition and $250 \mathrm{x}$ magnification

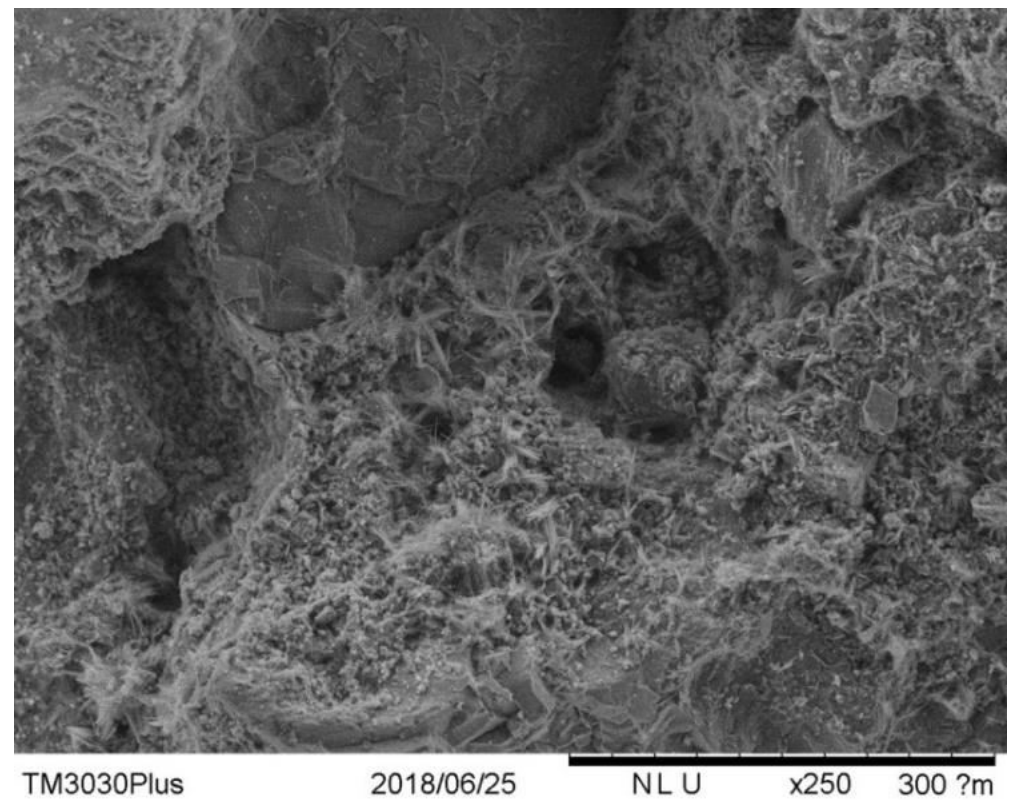

Fig. 9. SEM test of paving block with $7.5 \%$ tile waste addition and $250 \mathrm{x}$ magnification 


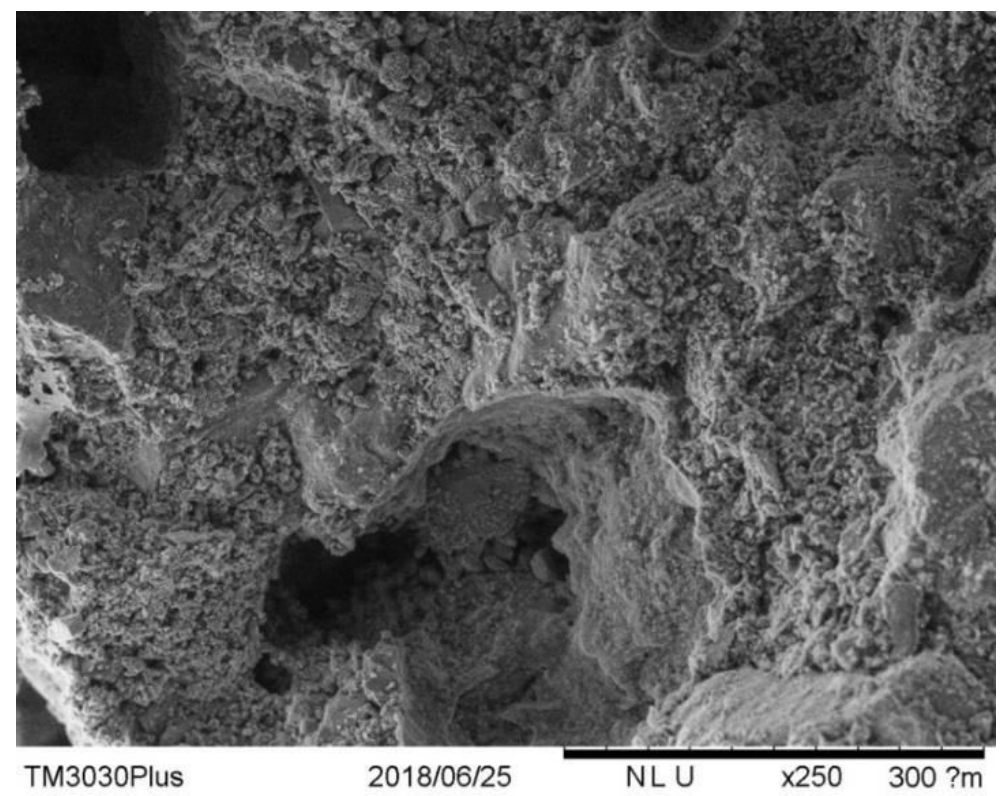

Fig. 10. SEM test of paving block with $10 \%$ tile waste addition and $250 x$ magnification

Figures 8,9 and 10 are the results of the SEM paving block test with the addition of tile waste each of $5 \%, 7.5 \%$ and $10 \%$. In the figure shows the existence of the cavity produced due to the reduced level of homogeneity of its constituent materials such as cement, waste roof, sand, and water. From Figure 8, 9 and 10 it can be seen that the increasing use of tile waste as a substitution of cement makes the homogeneity of paving block become less and tend to cause cavity in paving block. SEM test results above also support the value of water absorption test on paving block. The increasing percentage of tile waste makes the value of water absorption or porosity becomes increasing as the volume of empty cavities produced more and more. These cavities that make the compressive strength of paving block become decreased every level of percentage addition of tile waste. The conclusion of the SEM test is that the higher percentage of tile waste on paving block making makes more cavities in the paving block due to its low homogeneity due to the decreasing of cement content as the main binder material of paving block mixture substituted by tile waste.

\section{Conclusion}

a. By raising the temperature of fuel, the compressive strength of the paving block increased by $5.9 \%$. However, by increasing the percentage of addition of tile waste into paving block mixture, the resulting compressive strength decreased by $7.2 \%$.

b. Variations that meet the requirements of water absorption are the variations in the temperature of burning tile waste $750{ }^{\circ} \mathrm{C}, 800{ }^{\circ} \mathrm{C}, 850{ }^{\circ} \mathrm{C}$, and $900{ }^{\circ} \mathrm{C}$ percentage of $5 \%$ with water absorption value $4,81 \%, 5,01 \%, 4.94 \%$ and $2.51 \%$ respectively.

c. The more percentage of tile waste in paving block making makes more cavities in the paving block due to its low homogeneity due to the decrease of cement content as the main binder of paving block mixture substituted by tile waste. 


\section{Suggestion}

a. Advanced research is required by raising the fuel temperature above $900^{\circ} \mathrm{C}$ to find the result of a more amorphous compound and its effect on compressive strength

b. A more detailed chemical analysis is needed to determine the effect of each compound on the mechanical properties of the specimen

c. Further research is required to produce increased compressive strength with the addition of tile waste utilization

\section{References}

1. Ade ilham. Effect of Physical Properties and Chemistry of Pozzolan Materials on High Performance Concrete.Volume 13, No.3. (2005)

2. Adi, W. K. Synthesis and Characterization of Nanoparticles and TiO2 Nanotubes for the Application of Solar Cells Dyestuffed Dyes. Depok: Faculty of Engineering University of Indonesia (2012)

3. ASTM C 618-94, Standard Specification for Cosl Fly Ash and Raw or Calcined Natural Pozzolan for Use in Concrete. United States: Association of Standard Testing Materials.

4. National Standards Agency. SNI S-04-1989-F, Building Material Specification Part A.1989.

5. National Standardization Agency. SNI 03-1974-1990: Concrete Compressive Strength Testing Method. 1990

6. Baskaran, K and K. Gopinath, Study on applicability of ACI and DoE Mix Design Methods for Paving Blocks, The Institution of Engineers, Sri Lanka. (2013)

7. Bektas F., Alkali reactivity of crushed clay brick aggregate, USA: Iowa State University, Ames, IA. (2014)

8. Bragman, C.P and Goncalves, M.R.F. Thermal Insulators Made With Rice Husk Ashes: Production and Correlation Between Properties and Microstructure. Department of materials, school of engineering, federal university of rio grande do sul, Brasil. (2006)

9. Cotton, F. A. and Walkinson,G. Kimia Anorganik. UI Press. Jakarta. (1989)

10. Lea, F.M., The chemistry of cement and concrete (3rd edition). New York: (1970)

11. Frank Edwin, Evaluation of Deposit Characteristics of Gunung Kidul Train and Kulon Progo D.I.Y Yogyakarta as Substitution Material of Portland Cement: News Material Technology and Technical Products No.21. (2007)

12. Ridwan, Making Paving Block with Powdered Mixer Material Press Village Kunir Lumajang as Substitution of Cement, Jember: University of Jember (2017)

13. Robayo A Rafael, dkk,Alternative cements based on alkali-activated red clay brick waste. Colombia : Universidad del Valle, Cali. (2016) 